\title{
Assessment of Radionuclide Content of Shore Sediments Collected from the Bank of River Benue, North-Central Nigeria
}

\author{
Terver Somboํㅜ, Ejembi Emmanuel2, Jonathan Ugwuanyi ${ }^{1}$ \\ ${ }^{1}$ Department of Physics, University of Agriculture, Makurdi, Nigeria \\ ${ }^{2}$ Department of Natural and Applied Sciences, Namibia University of Science and Technology, Windhoek, Namibia \\ Email: emmy2save@yahoo.com
}

How to cite this paper: Sombo, T., Emmanuel, E. and Ugwuanyi, J. (2017) Assessment of Radionuclide Content of Shore Sediments Collected from the Bank of River Benue, North-Central Nigeria. Journal of Geoscience and Environment Protection, 5, 57-65.

https://doi.org/10.4236/gep.2017.512004

Received: November 2, 2017

Accepted: December 15, 2017

Published: December 18, 2017

Copyright $\odot 2017$ by authors and Scientific Research Publishing Inc. This work is licensed under the Creative Commons Attribution International License (CC BY 4.0).

http://creativecommons.org/licenses/by/4.0/

c) (i) Open Access

\begin{abstract}
Ionizing Radiation emitted from radionuclide has an adverse effect on human health. A continuing population exposure to naturally occurring radioactive materials (NORMS) found in our environment is one of the major scientific subjects that attract public attention. The assessment of radionuclide content of shore sediments of river Benue-North Central Nigeria was carried out using gamma-ray spectrometry. The activity concentrations of U-238, Th-232 and K-40 were found to have an average concentration of $1.17,3.31$ and $405.95 \mathrm{~Bq} \cdot \mathrm{kg}^{-1}$ respectively. The values gotten from present study were compared with the world average values. World average values of U-238, Th-232 and $\mathrm{K}-40$ are $50 \mathrm{~Bq} \cdot \mathrm{kg}^{-1}, 50 \mathrm{~Bq} \cdot \mathrm{kg}^{-1}$ and $500 \mathrm{~Bq} \cdot \mathrm{kg}^{-1}$ respectively. The mean concentration of daughter radionuclides generated from U-238, Th-232 was 4.32, 10.37, 5.24, 3.86, 11.87, and 6.52 for Bi-212, Pb-212, Bi-214, Pb-214, Ra-226 and Ac-228, respectively. The mean of the absorbed dose, Annual effective dose equivalent, for radium equivalent activity, and external hazard index, were evaluated to be $19.45 \mathrm{nGy} \cdot \mathrm{h}^{-1}, 23.82 \mu \mathrm{Sv} \cdot \mathrm{y}^{-1}, 37.16 \mathrm{~Bq} \cdot \mathrm{kg}^{-1}, 0.10$ $\mathrm{mSv} \cdot \mathrm{y}^{1}$, below the permissible limit of $57 \mathrm{nGy} \cdot \mathrm{h}^{-1}, 70 \mu \mathrm{Sv} \cdot \mathrm{y}^{-1}, 370 \mathrm{~Bq} \cdot \mathrm{kg}^{-1}$ and $1 \mathrm{mSv} \cdot \mathrm{y}^{-1}$ respectively. These shore sediments from river Benue are therefore, radiologically safe for construction and other domestic and industrial purposes.
\end{abstract}

\section{Keywords}

Radionuclides, Sediments, Gamma Spectrometry, Radiological Parameter

\section{Introduction}

Trace numbers of radionuclides such as U-238, U-235 and Th-232 occur in the 
soil, earth crust, water, air and vegetable [1]. These radionuclides decompose to produce stable atoms. During the decomposition process a series of radionuclides are generated, each of them having a wide range of half-lives. The radionuclides and their progeny significantly contribute to the radiation dose received by the public, when exposed internally or externally [2] [3]. According to Onjefu et al. [4], the major contribution of external dose of radiation to the world is from radionuclides elements, which are found in the soil, rock and geological material, and their progeny. This dose absorbs externally, and varies according to the radionuclides concentration that is containing in the earth material.

Exposure to ionizing radiation may be as a result of rays generated from the outer space and from the solar system and also naturally occurring radionuclides present in the environment, such as radionuclides from sediment, crusts from the rock, building material, air, in our food and also human body [5]. One of the major concerned that attract the attention of the public, is an exposure to these naturally occurring radioactive materials (NORMs) found in our environment [6]. Artificial radioactivity sources exposed include anthropogenic radionuclides such as Cs-137, Sr-90 etc., which are produced from nuclear bomb testing and nuclear accident [7]. From geological source, through activities, such as excavation of the earth crust and mining [8], chemical elements generated from geological process, contribute to the amount of ionizing radiation emitted from the environment [9].

Particulate matter such as dust particles, pollen grains, tiny particle of sand, etc., which can be transported from one place to another, by river or ocean flow is known as sediments. This can be deposited as solid particles on the coastline, river bank or to the environments [10]. According to Oyebanjo et al., [11], the origin of sediments is from geological earth crust, like rock sample and soil. From their investigations, it is confirmed that rocks and sand, contain varying amount of radionuclide; this particle can be transfer to the environment by wind, river and ocean current. The distribution of rocks, sand dunes and soil particle, increases the number of radionuclides distributed to the environment [12].

Radiation emitted from our terrestrial environment has been substantially investigated in different locations of the world. However, little has been done in this regards in North Central Nigeria. High radiation emitted from some part of the North Central Nigeria, especially in the Akwanga area, may be as a result of the geology and geographical altitude of the area [13]. Since shore sediments originate from geological earth crust like rock and soil samples, these can be transported by river or ocean flow; hence, river Benue is likely to contain radionuclides [10] [11] [12]. Studies by [8] [9] show that rivers shore sediments sample used for building have elevated levels of radioactivity. This has a potential of causing health hazards to the public living in houses, offices, class rooms etc build from shore sediments [8] [9]. The levels of natural radionuclides present in sediments may have an adverse effect to the wellbeing of people living in the environment [14]. The adverse effect of gamma irradiation dose on mammalian 
tissue was measured by Sombo et al. [15], they used a mathematical model to determine their dielectric dispersion properties. Exposure to ionizing radiation from sediments is regarded as a problem to human population and the environment. According to scientific community, any exposure to natural radioactivity carries its own level of harmful effect [16]. To address this problem, it is paramount to ascertain the type and quantity of radionuclides present in the shore sediments.

\section{Materials and Methods}

\subsection{Study Area}

This research work focuses on three regions along the coastline of river Benue within Makurdi Metropolis. The Benue State capital, Makurdi is located between latitudes $7^{\circ} 35^{\circ}-7^{\circ} 53 \mathrm{~N}$ and longitude $8^{\circ} 24-8^{\circ} 42 \mathrm{E}$. Its covers a land area of 800 $\mathrm{km}^{2}$ and has a population of 300,000 people (2006 census data). The city is around the flood plan of Benue river, which bisects the city into the northern and southern parts [17]. The climate conditions of Makurdi metropolis is strongly influence by the warm moist south-westerly air mass and the warm dry north-easterly air mass. Some part of the town is flooded during rainy season. The inhabitants of this study area are civil servants and peasant farmers [18]. The map of Makurdi showing the study area, is shown in Figure 1 below.

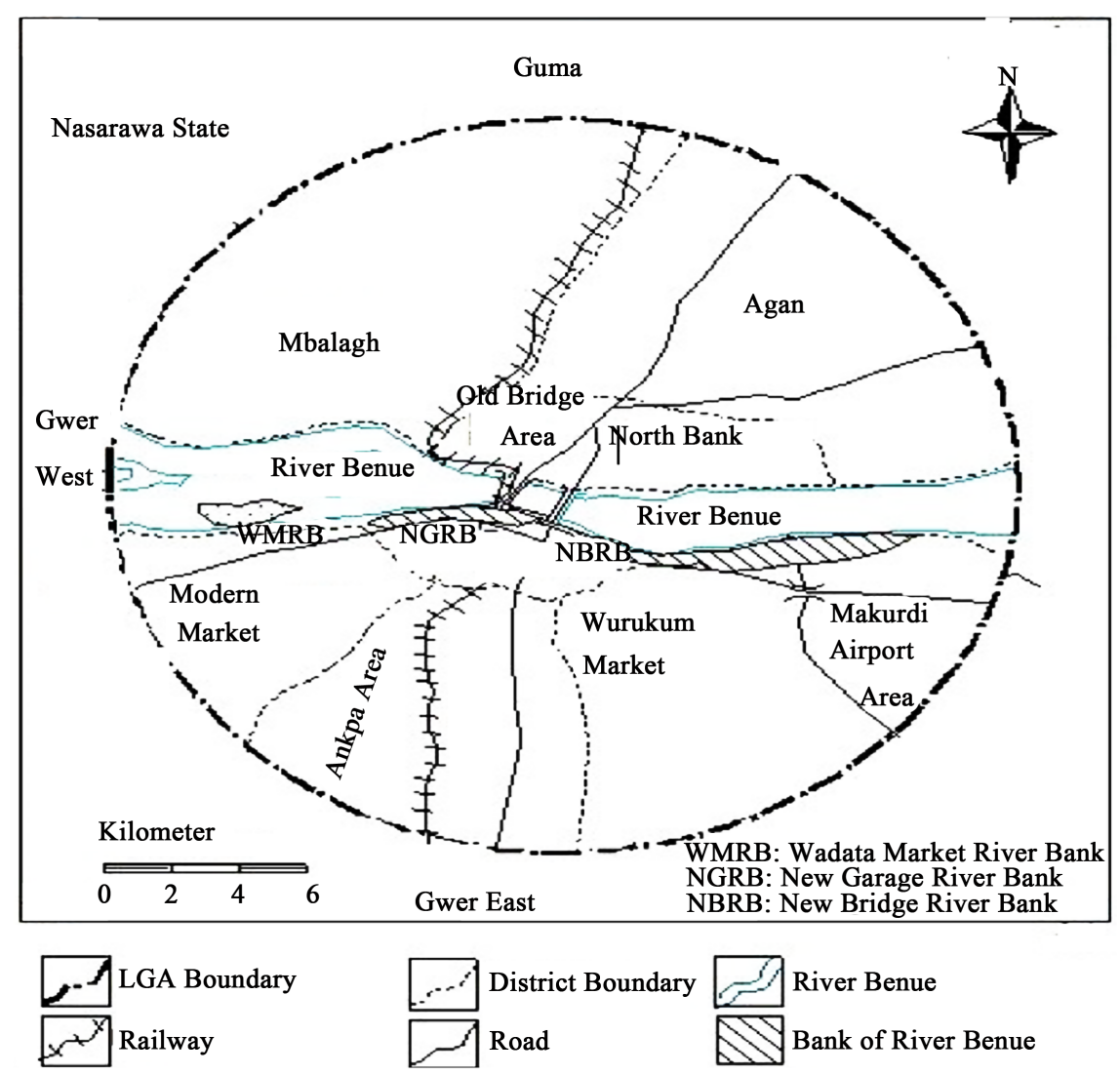

Figure 1. Map of Makurdi, Benue State showing the study areas. 


\subsection{Sample Collection and Pre-Treatment for Gamma Counting}

River sediment samples were collected at three locations of river Benue within Makurdi Metropolis, namely around (NBRB), New Garage Riverbank (NGRB) and Wadata Market Riverbank (WMRB). This location was selected based on the high level of human activities such as fishing, vegetable farming, extraction of sand and gravel etc. Hand auger was used to collect the samples, at distance of 1 - 2 metre away from the river edge and the middle of the river. These samples were packed in small plastic bags and sealed to prevent Rn-222 and Rn-220 from escaping out of the samples. The residual moisture in the samples was removed by placing them in an oven, and was heated to maintain a temperature of about $110^{\circ} \mathrm{C}$ for 24 hours, a gamma spectrometric assembly with a high purity germanium detector (HPGe). Located at Namibia University of Science and Technology Postgraduate laboratory was then used to count the sample for 28800 seconds ( 8 hours). The detector contains $70 \%$ efficiency and a resolution of 1.8 $\mathrm{keV}$ at the $1.3 \mathrm{MeV}$ of Cobalt-60 source. The HPGe detector was calibrated using standards of known concentration of radioisotopes for energy and efficiency before measurements were taken. The background was monitored and subsequently subtracted from the spectrum of gamma radiation from each sample to obtain net counts for the samples. The spectrum of each standard was later used to obtain energy calibration.

\subsection{Determination of Radiological Parameters.}

The absorbed dose rate $(D)$, Annual effective Dose equivalent (AEDE), Radium equivalent activity (Raeq), and External hazard index (Hex) were estimated using Equations (1)-(4) respectively [5] [19] [20] [21].

$$
D\left(\mathrm{nGy} \cdot \mathrm{h}^{-1}\right)=0.462 A_{\mathrm{Ra}}+0.604 A_{\mathrm{Th}}+0.0417 A_{\mathrm{K}}
$$

where $D$ represent the absorbed dose rate, ARa, ATh and AK represent the concentration of Ra-226 (U-238), Th-232 and K-40, respectively.

$$
\operatorname{AEDE}\left(\mu \mathrm{Sv} \cdot \mathrm{y}^{-1}\right)=D\left(\mathrm{nGy} \cdot \mathrm{h}^{-1}\right) \times 8760 \mathrm{~h} \times 0.2 \times 0.7 \mathrm{~Sv} \cdot \mathrm{Gy}^{-1} \times 10^{-3}
$$

where the conversion coefficient is represented as $0.7 \mathrm{~Sv} \cdot \mathrm{Gy}^{-1}$ and 0.2 is the outdoor occupancy factor.

$$
R a_{e q}\left(\mathrm{~Bq} \cdot \mathrm{kg}^{-1}\right)=A_{\mathrm{Ra}}+1.43 A_{\mathrm{Th}}+0.077 A_{\mathrm{K}}
$$

where ARa, ATh and AK are the activity concentration of Ra-226, Th-232 and $\mathrm{K}-40$ in $\mathrm{Bq} \cdot \mathrm{kg}^{-1}$, respectively.

$$
H_{E X}=\left(\frac{A_{\mathrm{Ra}}}{370}\right)+\left(\frac{A_{\mathrm{Th}}}{259}\right)+\left(\frac{A_{\mathrm{K}}}{4810}\right) \leq 1
$$

Values of the external hazard index must not be more than the required limit, this help to reduce the effect of radiation hazard from the environment. The maximum value of Hex equal to unity corresponds to the upper limit of radium equivalent activity $370 \mathrm{~Bq} \cdot \mathrm{kg}^{-1}$ [21]. 


\section{Results and Discussion}

\subsection{Activity Concentrations}

The activity concentration of U-238, Th-232 and K-40 were measured from all the sample collected along the river coastline within Makurdi municipal area. The mean concentration of the radionuclides for the three locations were calculated as presented in Table 1, and their comparisons are shown in Figure 2. The obtained result shown that the mean activity concentration of U-238 was found to ranges from $0.98 \mathrm{~Bq} \cdot \mathrm{kg}^{-1}-2.01 \mathrm{~Bq} \cdot \mathrm{kg}^{-1}$, with mean value $(1.17 \pm 0.62) \mathrm{Bq} \cdot \mathrm{kg}^{-1}$. Th-232 ranges from $3.17 \mathrm{~Bq} \cdot \mathrm{kg}^{-1}-3.99 \mathrm{~Bq} \cdot \mathrm{kg}^{-1}$. With mean value of $(3.31 \pm 0.50)$ $\mathrm{Bq} \cdot \mathrm{kg}^{-1}$. While $\mathrm{K}-40$ activity concentration ranged between $73.98 \mathrm{~Bq} \cdot \mathrm{kg}^{-1}$ $571.94 \mathrm{~Bq} \cdot \mathrm{kg}^{-1}$, with mean value of $(405.94 \pm 234.86) \mathrm{Bq} \cdot \mathrm{kg}^{-1} . \mathrm{K}-40$ recorded the highest activity concentration in all the samples. This may be because of the geological granitic formations of the river bed and potassium fertilizers that are usually washed by run-off into the river during rainy season.

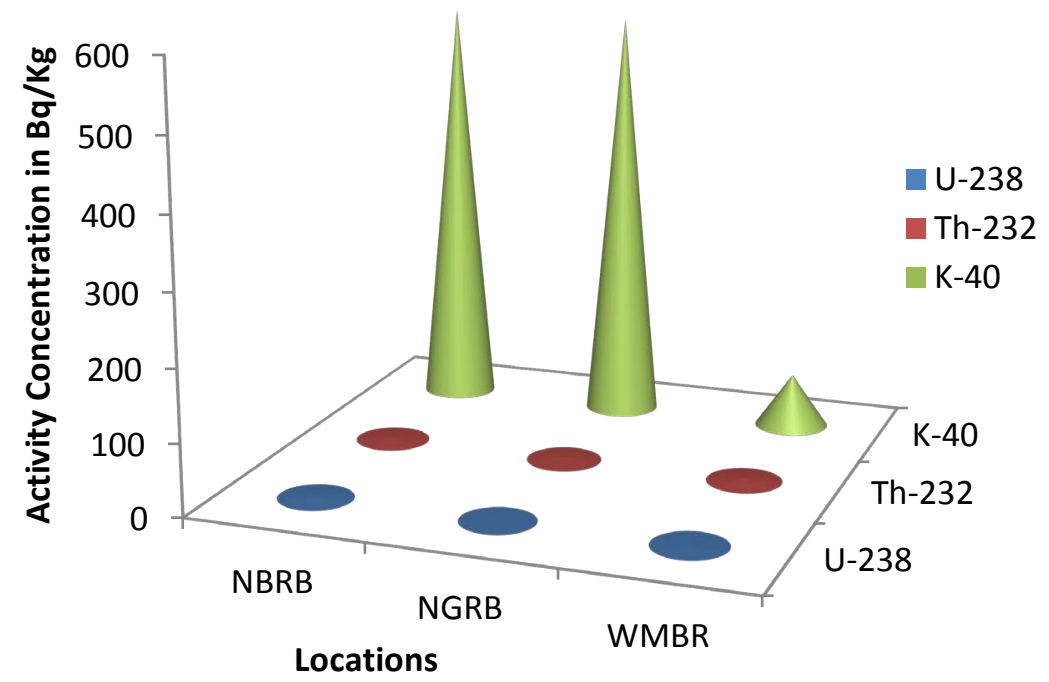

Figure 2. Comparison of mean activity concentration of natural radionuclides.

Table 1. Mean activity concentration of natural radionuclides, along the three site locations of River Benue, Makurdi. (New Bridge River Bank "NBRB”, New Garage River Bank “NGRB”, Wadata Market River Bank “WMRB”).

\begin{tabular}{cccc}
\hline \multirow{2}{*}{ Locations } & \multicolumn{3}{c}{ Activity Concentration $(\mathrm{Bq} / \mathrm{kg})$} \\
\cline { 2 - 4 } & $\mathrm{U}-238$ & Th-232 & $\mathrm{K}-40$ \\
\hline NBRB & 2.01 & 3.17 & 571.91 \\
NGRB & 0.52 & 2.78 & 571.94 \\
WMRB & 0.98 & 3.99 & 73.98 \\
Mean & 1.17 & 3.31 & 405.94 \\
Standard Deviation & \pm 0.62 & \pm 0.50 & \pm 234.86 \\
Maximum & 2.01 & 3.99 & 571.94 \\
Minimum & 0.52 & 2.78 & 73.98 \\
\hline
\end{tabular}


The presence of daughter radionuclides from U-238 and Th-232 such as Bi-212, Bi-214, Pb-212, Pb-214, Ra-226 and Ac-228 were detected in all the samples as presented in Table 2 and Figure 3. Ra-226 has the highest activity concentration of $11.87 \mathrm{~Bq} \cdot \mathrm{kg}^{-1}$, closely followed by $\mathrm{Pb}-212$. The rest of the progenies recorded activity concentration between $3.86-6.52 \mathrm{~Bq} \cdot \mathrm{kg}^{-1}$ with $\mathrm{Pb}-214$ having the least activity concentration.

\subsection{Units}

- Use NB

New Bridge River Bank "NBRB” Sediment Sample recorded the highest activity Concentration of U-238, Bi-214, Pb-214 and Ac-228 while Wadata Market River Bank "WMRB" Sediment Samples recorded the highest activity Concentration of Th-232, K-40 and Ra-226. The highest concentration of Bi-212 and $\mathrm{Pb}-212$ were found in sediment samples from New Garage River Bank "NGRB" Site.

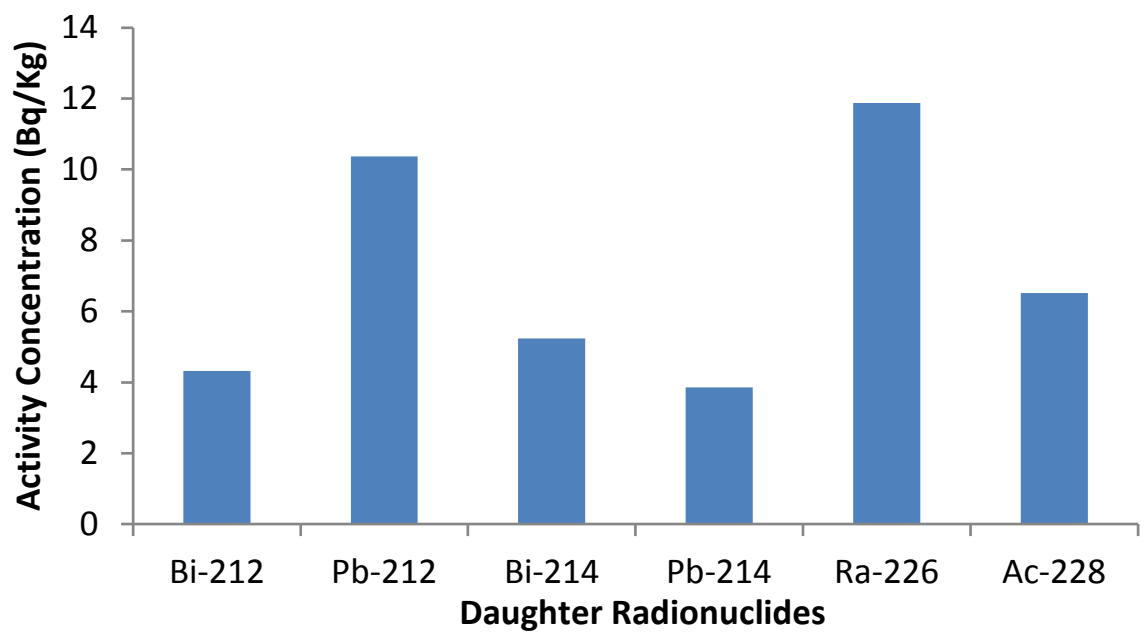

Figure 3. Mean activity concentration of daughter radionuclides.

Table 2. Mean activities concentration of daughter radionuclides found in sediments from River Benue Makurdi (RBM).

\begin{tabular}{ccccccc}
\hline \multirow{2}{*}{ Location(RBM) } & \multicolumn{7}{c}{ Activity Concentration (Bq/kg) } \\
\cline { 2 - 7 } & Bi-212 & Pb-212 & Bi-214 & Pb-214 & Ra-226 & Ac-228 \\
\hline NBRB & 5.73 & 9.84 & 6.57 & 5.55 & 18.30 & 11.22 \\
NGRB & 7.05 & 15.82 & 3.87 & 3.44 & 8.46 & 5.12 \\
WMRB & 0.17 & 5.44 & 5.28 & 2.60 & 8.86 & 5.12 \\
Mean & 4.32 & 10.37 & 5.24 & 3.86 & 11.87 & 6.52 \\
Standard Deviation & \pm 2.98 & \pm 4.25 & \pm 1.10 & \pm 1.24 & \pm 4.55 & \pm 2.94 \\
Maximum & 7.05 & 15.82 & 6.57 & 5.55 & 18.30 & 11.22 \\
Minimum & 0.17 & 5.44 & 3.87 & 2.60 & 8.46 & 3.21 \\
\hline
\end{tabular}


Table 3 represents the comparison of the activity concentration of U-238 and Th-232 found in river Benue and that of other rivers, this implies that, U-238 and Th-232 concentration, found in River Benue are far lower than those of ponnaiyer rivers-India, Osun river-Nigeria, Charfassion Island-Banglandish and Coastline of Erongo region-Namibia, while the Concentration of K-40 is greater than those of the above-mentioned references except that of charfassion Island-Banglandesh.

The absorbed dose $(D)$, Annual effective dose equivalent (AEDE), Radium equivalent activity (Raeq) and Hazard index from river Benue Sediments were found to be $19.45 \mathrm{nGy} \cdot \mathrm{h}^{-1}, 23.82 \mu \mathrm{Sv} \cdot \mathrm{y}^{-1}, 37.16 \mathrm{~Bq} \cdot \mathrm{kg}^{-1}$ and $0.1 \mathrm{mSv} \cdot \mathrm{y}^{-1}$ respectively as shown in Table 4 and their comparisons with works of other researchers is presented in Table 5. These parameters were found to be less than their

Table 3. Comparison of activity concentration of U-238, Th-232 and K-40 in shore Sediments samples from River Benue and that of other rivers [4] [11] [22].

\begin{tabular}{cccccc}
\hline \multirow{2}{*}{ Locations } & \multicolumn{3}{c}{ Activity Concentration (Bq/kg) } & Reference \\
\cline { 2 - 4 } & U-238 & Th-232 & K-40 & \\
\hline River Benue, Makurdi & 1.17 & 3.31 & 405.94 & & Present study \\
Osun River, Nigeria & 24.00 & 35.70 & 162.38 & Oyebanjo et al., 2012 \\
Charfassion Island, Bhola Banglandesh & 16.82 & 32.84 & 743.52 & & Nizam et al., 2013 \\
Coastline of Erongo Region Namibia & 173 & 37.77 & 441.78 & & Onjefu et al., 2016 \\
\hline
\end{tabular}

Table 4. The absorbed dose rate, annual effective dose equivalent, radium equivalent and radiological hazard index of sediment samples from river Benue.

\begin{tabular}{ccccc}
\hline Location $(\mathrm{RBM})$ & $\mathrm{D}\left(\mathrm{nGy} \cdot \mathrm{h}^{-1}\right)$ & $\mathrm{AEDE}\left(\mu \mathrm{Sv} \cdot \mathrm{y}^{-1}\right)$ & $\mathrm{Ra}_{\mathrm{eq}}\left(\mathrm{Bq} \cdot \mathrm{kg}^{-1}\right)$ & $\mathrm{H}_{\mathrm{ex}}$ \\
\hline NBRB & 26.57 & 32.59 & 50.58 & 0.14 \\
NGRB & 25.77 & 31.60 & 48.53 & 0.13 \\
WMRB & 5.95 & 7.30 & 12.38 & 0.03 \\
Mean & 19.42 & 23.82 & 37.16 & 0.10 \\
Maximum & 26.57 & 32.59 & 50.58 & 0.14 \\
Minimum & 5.95 & 7.30 & 12.38 & 0.03 \\
\hline
\end{tabular}

Table 5. Comparison of calculated absorbed dose rate, annual effective dose equivalent, Radium equivalent and radiological hazard index of river Benue sediment samples and that of other rivers [4] [5] [22].

\begin{tabular}{cccccc}
\hline Location(RBM) & $\mathrm{D}\left(\mathrm{nGy} \cdot \mathrm{h}^{-1}\right)$ & $\mathrm{AEDE}\left(\mu \mathrm{Sv} \cdot \mathrm{y}^{-1}\right)$ & $\mathrm{Ra}_{\mathrm{eq}}\left(\mathrm{Bq} \cdot \mathrm{kg}^{-1}\right)$ & $\mathrm{H}_{\mathrm{ex}}$ & Reference \\
\hline $\begin{array}{c}\text { River Benue Makurdi } \\
\text { Charfassion Island, }\end{array}$ & 19.42 & 23.82 & 37.16 & 0.10 & Present study \\
$\begin{array}{c}\text { Bhola, Banglandes } \\
\text { Coastline of Erongo } \\
\text { Region Namibia }\end{array}$ & 58.61 & 0.07 & 120.93 & - & Nizam et al., 2013 \\
\begin{tabular}{c} 
Worldwide Average \\
\hline
\end{tabular} & 57 & 339.36 & - & - & Onjefu et al., 2016 \\
\hline
\end{tabular}


respective permissible levels of $57 \mathrm{nGy} \cdot \mathrm{h}^{-1}$ [5], $70 \mu \mathrm{Sv} \cdot \mathrm{y}^{-1}$ [5], $370 \mathrm{~Bq} \cdot \mathrm{kg}^{-1}$ [22] and $1 \mathrm{mSv} \cdot \mathrm{y}^{-1}$ [23]. The result of this work shows that the level of natural radionuclides and their progenies found in sediment samples within Makurdi municipal area have insignificant radiological health hazard.

\section{Conclusions}

The following natural radionuclides U-238, Th-232, K-40 and their progenies, Bi-212, Pb-214, Pb-214 Ra-226 and Ac-228 were detected in the shore sediments of River Benue along Makurdi municipality area. Their activity concentration and calculated radiological parameter (Absorbed dose D, Annual effective dose equivalent AEDE, Radium equivalent Raeq, and External hazard index Hex) were found to be below their respectively permissible safety limits.

This research study was carried out along the bank of River Benue, Makurdi, Nigeria. Future research studies on Activity Concentration of Radionuclide, can also be carried out in the industrial area of the City of Makurdi, where human activities are of high increase. This will help investigate and monitor the amount of ionizing radiation emitted to the environment.

\section{Acknowledgements}

We sincerely appreciate Namibia University of Science and Technology for assisting us during gamma spectrometry analysis.

\section{References}

[1] Balakrishna, R.S. (2007) Distribution of U-Th nuclides in the Riverine and Coastal Environments of the Tropical South West Coast of India. Journal of Environmental Radioactivity, 57, 21-33. https://doi.org/10.1016/S0265-931X(00)00215-0

[2] Cooper, M. (2006) National Occurring Radioactive Materials (NORM) in Australian Industries Review of Current Inventories and Future Generation. Australia.

[3] Abel-Ghang, H.E.-Z. (2007) Environmental Radioactivity Measurements of Some Egyptian Sand Samples. Ain-Shams University, Cairo.

[4] Onjefu, A., Kgabi, A., Simeon, H., Taole, O., Mtambo, P.I., Charles, G. and Antoine, J. (2016) Occupancy Factor Model for Exposure to Natural Radionuclides along the Coastline of Erongo Region, Namibia. Journal of Geoscience and Environmental Protection, 4, 117-126. https://doi.org/10.4236/gep.2016.45012

[5] UNSCEAR (2000) Sources and Effects of Ionizing Radiation: United Nations Scientific Committee on Effects of Atomic Radiation. Report to the General Assembly with Scientific Annexes, Vol. 1.

[6] UNEP (2012) Lead Pollution and Poisoning Crisis: United Nation Environment Programme. Report of Environmental Emergency Response Mission in Zamfara State Nigeria. Zamfara State, Nigeria.

[7] Hu, Q.W. (2010) Sources of Anthropogenic Radionuclides in the Environment: A Review. Journal of Environmental Radioactivity, 101, 426-437. https://doi.org/10.1016/j.jenvrad.2008.08.004

[8] Ramasamy, V.S. (2009) Measurement of Natural Radioactivity in Beach Sediments from North East Coast of Tamilnadu, India. Research Journal of Applied Science 
Engineering and Technology, 1, 54-58.

[9] Pereira, A.N. (2012) Estimation of the Radiological Background and Dose Assessment in Areas with Naturally Occurring Uranium Geochemical Anomalies. Journal of Environmental Radioactivity, 112, 96-107. https://doi.org/10.1016/j.jenvrad.2012.05.022

[10] Omale, P.O. (2014) Determination for Levels of Radionuclides of Uranium, Thorium and Potassium in Water, Sediments and Algae Samples from Selected Coastal Area of Lagos, Nigeria; Using Energy Dispersive X-Ray Fluorescence. Global Journal of Pure and Applied Chemistry Research, 2, 1-24.

[11] Oyebanjo, O.J. (2012) Natural Radionuclides and Hazards of Sediment Samples Collected from Osun River in Southwestern Nigeria. The Pacific Journal of Science and Technology, 13, 391-396.

[12] Sonon, L.S., Chappell, M.A. and Evangelou, V.P. (2007) The History of Soil Chemistry. Journal of Science Total Environment, 35, 88-90.

[13] Sadiq, A.A. and Agba, E.A. (2011) Background Radiation in Akwanga, Nigeria. Working and Living Environmental Protection, 8, 7-11.

[14] Ngachin, M.G. (2007) Assessment of Natural Radioactivity and Associated Radiation Hazards in Some Cameroonian Building Material. Radiation Measurement, 42, 61-67. https://doi.org/10.1016/j.radmeas.2006.07.007

[15] Sombo, T., Ige, T.A. and Agba, E.H. (2015) Mathematical Modelling of the Effects of Gamma Irradiation on Dielectric Dispersion of Bovine Liver Tissue at Low and Radiofrequency. International Journal of Biophysics, 5, 12-17.

[16] BEIR VLL Phase 2 (2006) Health Risks from Exposure to Low Levels of Ionizing Radiation. National Academics Press, Washington DC.

[17] Bernard, T.T. and Raymond, N.C. (2012) Analysis of Surface Urban Heart Island in Makurdi. Department of Geography Benue State University, Makurdi.

[18] Ologunorisa, T. and Tersoo, T. (2006) The Changing Rainfall Pattern and Its Implication for Flood Frequency in Makurdi, Northern Nigeria. Journal of Applied Sciences and Environmental Management, 10, 97-102.

[19] Singh, S. and Rakesh, K. (2005) Ra-226, Th-232 and K-40 Analysis in Soil Sample from Some Area of Punjab and Himachal Pradesh, India using Gamma Ray Spectrometry. Radiation Measurements, 39, 431-439. https://doi.org/10.1016/j.radmeas.2004.09.003

[20] Ajayi, O.S. (2009) Measurement of Activity Concentrations of 40K, 226Ra and 232Th for Assessment of Radiation Hazards from Soils of the Southwestern Region of Nigeria. Radiation and Environmental Biophysics, 48, 323-332. https://doi.org/10.1007/s00411-009-0225-0

[21] Kumar, A., Kumar, M., Singh, B. and Singh, S. (2003) Natural Activities of U-232, Th-238 and K-40 in Some India Building Materials. Radiation Measurement, 36, 465-469. https://doi.org/10.1016/S1350-4487(03)00173-2

[22] Nizam, Q.M.R., Ginnah, M.A., Rahman, M.M. and Chowdhury, M.I. (2013) Assessment of Activity Concentrations of Radionuclides from Upper Level Sediment in Charfassion Island, Bhola, Bangladesh. Journal of Nuclear and Particle Physics, 3, 36-39.

[23] Belivernis, M., Kilic, N., Cotuk, Y. and Topcuoglu, S. (2010) The Effects of Physicochemical Properties on Gamma Emitting Natural Radionuclide Levels in the Soil Profile of Istanbul. Environmental Monitoring and Assessment, 163, 15-26. https://doi.org/10.1007/s10661-009-0812-1 